\title{
非円形プーリによるカ／トルクプロファイル調節機構の解析的設計法*
}

浅井 勝彦*1

\section{Analytical Design Methods of The Force/Torque Profile Adjustment Mechanism with a Non-Circular Pulley}

Katsuhiko ASAI ${ }^{* 1}$

${ }^{*}$ Advanced Technology Research Laboratory, Panasonic Corporation 3-4 Hikaridai, Seika-cho, Soraku-gun, Kyoto 619-0237, Japan

In this research, I investigated the design of non-circular pulley for a force/torque profile adjustment mechanism. I proposed the generalized analytical design method of the non-circular pulley applicable to the majority of structures. By using this design method, the torque acting on the non-circular pulley and the force acting on the flexible part twisted around the non-circular pulley can be converted mutually to obtain a desired torque/force profile. Also I demonstrated the design of the non-circular pulley for a spring balancer and for an arm weight compensation mechanism. Furthermore, I investigated the design limit of the non-circular pulley, and showed that too long effective radius, too long offset length, and too short radius of curvature cause the problem of impractical non-circular pulley shape. From the analysis of the occurrence condition of each case, it became clear that the derivative of the effective radius is important for avoiding too long offset length and that the effective radius and the second derivative of that are important for avoiding too short radius of curvature.

Key Words : Pulley, Force/Torque Profile, Design Method, Weight Compensation, Balancer, Mechanism, Balancing, Material Handling Equipment

\section{1. 緒言}

角度により半径か変化する非円形のプーリを用いることで, プーリに作用するトルクとプーリに巻き付けられた ワイヤやベルト等の可撓性部材に作用する張力との対応関係をプーリの角度に応じて変化させられることが知ら れている(1) (9) . ゼンマイバネの発生トルクを, 渦巻き状のプーリを用いることで一樣なワイヤ張力に変換し, 吊 り下げた物体の重量と釣り合わせるスプリングバランサは広く市販されており，光の設計法の検討が小林により 行われている(1)(2). 岡田は, 管内走行車のパンダグラフ機構に一樣な突っ張り力を発生させるために, 非円形プー リとバネの組合せを適用することを提案している(3). Ulrich らは, 平行に配置された 2 本の線形バネによるトルク が拮抗して非円プーリに作用する構成におけるプーリ外形を解析的に求め，2 自由度シリアルリンク系での重力補 償に適用している ${ }^{(4)}$. 広瀬らは , 形状記憶合金アクチュエータの出力特性を改善するために非円形プーリを用い るとともに, 数値計算によるプーリ外形の導出法を提案している ${ }^{(6)}$. さらに遠藤らは, この導出法を拡張して求め た非円形プーリを線形バネと組み合わせて 2 自由度平行リンク型アームの重力補償に適用し, 光の効果を示して いる ${ }^{(7)}$ (8) また Shin らは, この導出法を空気圧人工筋の拮抗駆動におけるトルク特性改善に適用している(9).

これまでの先行研究における非円形プーリの外形の導出方法は, 非円形プーリからの可撓性部材の引き出し方 向が一定であると仮定した解析的手法 ${ }^{(1)(2)(4)(5)}$ と，一端が回転自由に拘束された弾性要素に非円形プーリから引 き出された可撓性部材が連結される構成に対する数值的繰り返し計算手法 ${ }^{(6)}{ }^{(9)}$ とに大別される.すなわち，可撓 性部材に連結した弾性要素により非円形プーリに所定のトルクを発生させる構成の場合, 解析的手法を適用する

* 原稿受付 2013 年 1 月 8 日

*1 正員，パナソニック(株) 先端技術研究所（テ619-0237 京都府相楽郡精華町光台 3-4）

E-mail: asai.k@jp.panasonic.com 
ためには, 弾性要素の拘束点を可撓性部材の引き出し方向が一定と見なせる程遠方に設定するか, 引き出し方向 に垂直な方向に弾性要素が自由に変位できる構成にする必要がある．また数値的繰り返し計算手法を適用するた めには，一端を回転自由に拘束した弾性要素に可撓性部材を直接連結する必要がある．逆に，非円形プーリ側に 連結した弾性要素により可撓性部材に所定の張力を発生させる構成の場合，解析的手法を適用するためには，非 円形プーリからの可撓性部材の引き出し方向が一定となるように, 可撓性部材で荷物を直接吊り上げる構成等に する必要がある . また，数值的繰り返し計算手法は弚のまま適用することはできない．弚のため，現状では非円 形プーリの外形が導出できる構成が限られるとともに, 設計上の限界に対する知見も十分に得られていなかった。

一方で, カとトルクを変換して所望の特性を実現するという点では, トルク補償カムか類似していると考えら れる ${ }^{(10)}$. 設計において運動エネルギ一変化が一致するように変位と角変位を対応付ける点については同樣である が , 圧力角が重要なトルク補償力ムの設計と有効半径が重要な非円形プーリの設計とでは設計法や設計限界が異 なるため, 非円形プーリに対しては独自の設計法を構築することが必要になる .

本研究では, カ/トルクプロファイル調節機構における非円形プーリの設計に対して, 従来設計が困難だった 樣々な構成に対応できる解析的手法を提案し，任意の力／トルクプロファイルに対応できる設計手順を示す .さら に，解析により得られる非円形プーリの形状が実現不可能な結果になる条件を明らかにするとともに，兴の際の 対応策について述べる。

\section{2. 非円形プーリによるカ/トルクプロファイル調節機構}

\section{$2 \cdot 1$ 非円形プーリの形状}

非円形プーリと可撓性部材の組み合わせにより, カとトルクの相互変換 , プロファイル調節が可能になる .この 構成を組み合わせることで, トルク同士でのプロファイル調節や，力同士でのプロファイル調節も可能になるの で, 基本となる非円形プーリと可撓性部材の組み合わせの設計が行えれば，樣々な応用ができることになる．乥 こで, 非円形プーリの角変位 $\theta$ において , 非円形プーリに作用するトルク $\tau(\theta)$, 非円形プーリより引き出された 可撓性部材の張力 $F(\theta)$, 非円形プーリの回転中心から非円形プーリより引き出された可撓性部材までの距離にあ たる有効半径 $r(\theta)$ の関係が，

$$
r(\theta)=\frac{\tau(\theta)}{F(\theta)} \geqq 0
$$

で表される構成について考える . 任意のトルクプロファイル $\tau(\theta)$ と任意のカプロファイル $F(\theta)$ から求められる $r(\theta)$ を実現できる非円形プーリか設計できるようになれば， $\tau(\theta)$ と $F(\theta)$ の変換，調節が自由に行えるようにな る.しかし, 可撓性部材の引き出し方向が一定となる場合に限っても, 単純に角変位 $\theta$ において中心からの距離 が $r(\theta)$ となる形状の非円形プーリを用いれば良いわけではなく，中心から引き出し方向と平行に $d r / d \theta$ だけオフ セットさせた位置からの距離が $r(\theta)$ となる形状の非円形プーリでないと有効半径 $r(\theta)$ は実現できないことが示さ れている(4).

本節では, 有効半径 $r(\theta)$ を実現するプーリ形状を, 図 1 に示す可撓性部材の引き出し方向か変動する調節機構 のモデルを対象に解析的に求め, より広範囲な構成に対応できるようにする . 図 1 のモデルは, 有効半径 $r$ の非 円形プーリから引き出された可撓性部材を，中心が $b$ だけ離れた位置にある半径 $r_{r}$ の円形プーリに掛けることで， 最終的な引き出し位置を固定できるようにしている．可撓性部材の円形プーリへの掛け方は, (a) 逆曲げ，(b) 順曲 げの二種類となる .このような構成に対して設計が行えるようになれば，非円形プーリより引き出された可撓性 部材の取り得る三つの主要な選択肢，巻き付け $\left(r_{r} \neq 0\right)$, 吊り下げ $(b=\infty)$, 拘束 $\left(r_{r}=0\right)$ の全てに対して対応でき るようになる. 円形プーリからの可撓性部材の引き出し方向については, 以下の検討には影響しないので自由に 選択することができる. また, 可撓性部材を円形プーリから引き出す代わりに光のまま巻き付ける構成について も，同樣に取り扱うことができる . 図 1 では，非円形プーリの回転中心 $O$ と円形プーリの回転中心 $\mathrm{O}_{r}$ を通る直 線を $y$ 軸とし, 非円形プーリの回転中心 $\mathrm{O}$ を通り $y$ 軸と直行する直線を $x$ 軸としている. 非円形プーリの初期位 置からの角変位を $\theta$ とし, 時計回りを正としている. 非円形プーリに巻き付けられた可撓性部材は点 $\mathrm{P}$ を接点と して引き出され, 点 $\mathrm{S}$ を接点として円形プーリに掛けられている . このとき, 点 $\mathrm{P}$ と点 $\mathrm{S}$ を結っ湶が $y$ 軸の方向 となす角を $\phi$ と定義する.$\phi$ は，

$$
\phi=\sin ^{-1} \frac{r \pm r_{r}}{b}
$$




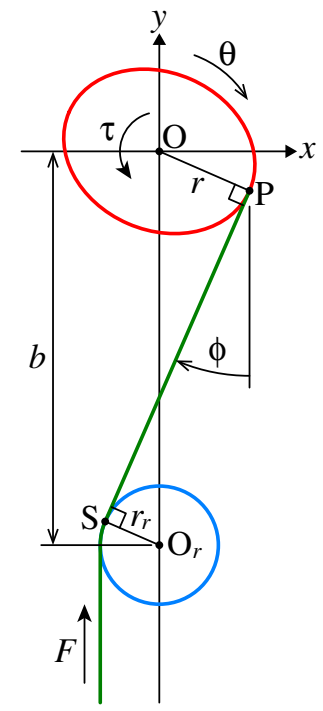

(a) Reverse Bending

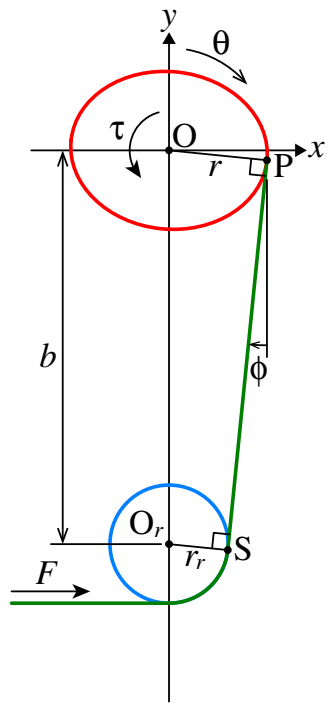

(b) Simple Bending

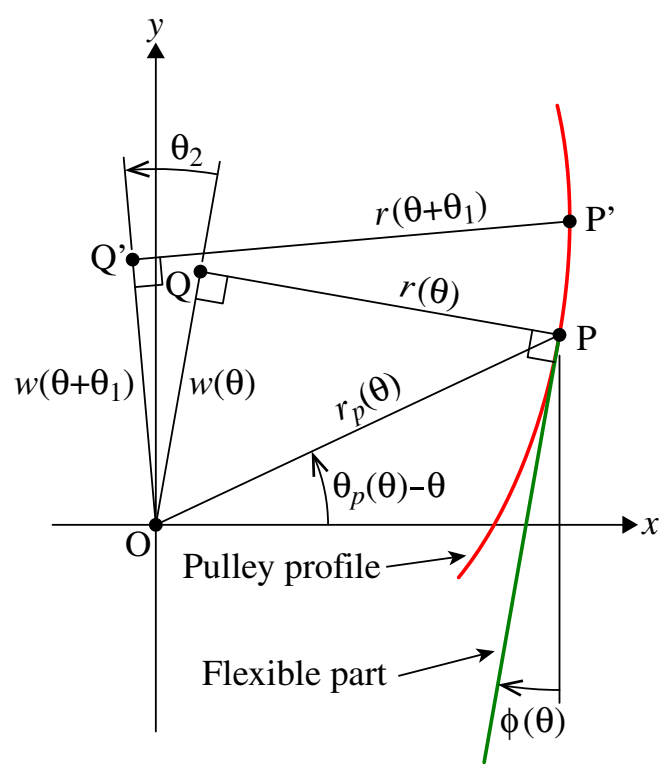

Fig. 1 Force/Torque profile adjustment mechanism.

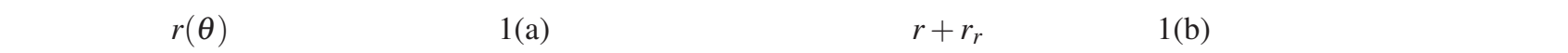
$r-r_{r}$ となる . 以下, 復号同順である $. b=\infty$ の場合 $\phi=0$ となるので, 可撓性部材の引き出し方向を一定とした 場合と等しくなることがわかる．

次に, 有効半径 $r(\theta)$ を実現する非円形プーリの形状について考える.図 2 に， $\theta$ だけ角変位した状態における 非円形プーリの形状と可撓性部材の関係を示す . 可撓性部材は点 $\mathrm{P}$ から引き出され, 有効半径が $r(\theta)$ であること から非円形プーリの回転中心 $\mathrm{O}$ からの距離が $r(\theta)$ となる.ここで, 点 $\mathrm{P}$ から可撓性部材と直行する方向に $r(\theta)$ だけ点 $\mathrm{O}$ 側に移動した点として点 $\mathrm{Q}$ を定義する.点 $\mathrm{O}$ と点 $\mathrm{Q}$ を結ぶ被は点 $\mathrm{P}$ から引き出される可撓性部材と平行 になる . 点 $\mathrm{O}$ と点 $\mathrm{Q}$ の間隔を $\theta$ の関数 $w(\theta)$ とし, 角変位 $\theta$ か変化しても常に有効半径 $r(\theta)$ が満たされる $w(\theta)$

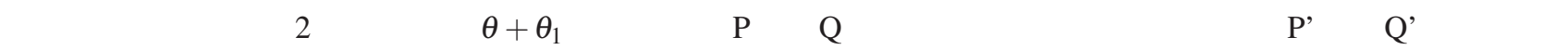
点 $\mathrm{P}$ 'は, 図 2 の状態からさらに $\theta_{1}$ だけ角変位したときに可撓性部材が引き出される接点になる . このとき, 有 効半径 $r$ の変化にともなって可撓性部材が引き出される方向を示す $\phi$ の值も変化するので, 直線 OQ と直線 OQ' のなす角 $\theta_{2}$ は，

$$
\theta_{2}=\theta_{1}-\phi\left(\theta+\theta_{1}\right)+\phi(\theta)
$$

と表される . 角変位 $\theta$ において点 $\mathrm{P}$ か接点となるための条件は, 直線 $\mathrm{OQ}$ と非円形プーリ外形上の各点との距離 が点 Pにおいて最大になることである．すなわち， $\theta_{1}$ が微小であるとして，

$$
\delta\left(\theta_{1}\right) \equiv\left(r+\frac{d r}{d \theta} \theta_{1}\right) \cos \theta_{2}-\left(w+\frac{d w}{d \theta} \theta_{1}\right) \sin \theta_{2}-r
$$

で与えられる点 $\mathrm{P}^{\prime}$ と直線 $\mathrm{OQ}$ の距離から点 $\mathrm{P}$ と直線 $\mathrm{OQ}$ の距離を引いた值が， $\theta_{1}=0$ において極大値をとるとい うことである.よって，

$$
\left(\frac{\partial \delta}{\partial \theta_{1}}\right)_{\theta_{1}=0}=0
$$

である . また $\theta_{1}$ が微小のとき, 式 (3) は式 (2)で示される $\phi$ の微分を用いて以下のように書き直すことができる .

$$
\theta_{2}=\left(1-\frac{d \phi}{d \theta}\right) \theta_{1}=\left[1-\frac{1}{\sqrt{b^{2}-\left(r \pm r_{r}\right)^{2}}} \frac{d r}{d \theta}\right] \theta_{1}
$$


式 (4) と式 (6) から式 (5) を解くと, 有効半径 $r(\theta)$ を実現するオフセット長 $w(\theta)$ として,

$$
w(\theta)=\frac{\sqrt{b^{2}-\left(r \pm r_{r}\right)^{2}}}{\sqrt{b^{2}-\left(r \pm r_{r}\right)^{2}}-\frac{d r}{d \theta}} \frac{d r}{d \theta}
$$

か導かれる.式(7) において $b=\infty$ とした場合には $w(\theta)=d r / d \theta$ となり，引き出し方向一定における解析結果と 一致する.結果として非円形プーリの形状は, 以下の動径 $r_{p}$, 偏角 $\theta_{p}$ で表される点 $\mathrm{P}$ の位置を, $\theta$ の動作範囲全 域にわたって点 $\mathrm{O}$ を中心する極座標上にプロットした形状となる .

$$
\begin{aligned}
& r_{p}(\theta)=\sqrt{r^{2}+w^{2}} \\
& \theta_{p}(\theta)=\theta-\sin ^{-1} \frac{r \pm r_{r}}{b}+\tan ^{-1} \frac{w}{r}
\end{aligned}
$$

ただし， $\theta_{p}$ は反時計回りが正であり，非円形プーリの角変位が 0 の状態における形状は， $x$ 軸方向を $\theta_{p}=0$ とし てプロットすることで得られる.得られた形状全体を時計回りに $\theta$ だけ回転させると，図 2 に相当する角变位 $\theta$ の状態における非円形プーリの形状となる .

しかし，実際に非円形プーリを製作する場合には，可撓性部材の厚みを考慮する必要がある．例えば，可撓性 部材が半径 $r_{w}$ のワイヤである場合, ワイヤの中心が有効半径 $r$ となる非円形プーリとするためには, 有効半径 $r$ を $r_{w}$ だけオフセットし，

$$
\begin{aligned}
r_{p}^{\prime}(\theta) & =\sqrt{\left(r-r_{w}\right)^{2}+w^{2}} \\
\theta_{p}^{\prime}(\theta) & =\theta-\sin ^{-1} \frac{r \pm r_{r}}{b}+\tan ^{-1} \frac{w}{r-r_{w}}
\end{aligned}
$$

として極座標上にプロットしなければならない . 同樣に , 円形プーリの半径も $r_{r}-r_{w}$ とする必要がある . 可撓性 部材として一樣なスチールベルトを用いる場合などは, 板厚の半分を $r_{w}$ として計算すればよい .

\section{$2 \cdot 2$ カ $/$ ルクプロファイル調節機構の設計手順}

以上, 調節機構に用いる非円形プーリの形状について述べてきたが , ここではまず出力としてトルクプロファイ ル $\tau(\theta)$ を実現する調節機構の設計手順について示す .このとき，可撓性部材に張力を作用させる入力側として想 定するのは, バネや鍾のように変位と発生力の関係が一定な機構である . ただし, 可撓性部材自体の伸びについ ては無視できるものとする .

1. 出力側の仕事量と見合う可撓性部材の変位 $u$ の範囲と, 可撓性部材に作用する張力についての力プロファイ ル $F(u)$ を初期設定する .

2. 可撓性部材の強度，寿命を考慮して， $r_{w}$ 及び許容できる最小曲率半径 $r_{c}$ を決定する．

3. 調節機構における基本寸法 $b, r_{r}$ や, 可撓性部材が順曲げか逆曲げかを初期設定する.

4. 同一の仕事量となる $\theta$ と $u$ との関係を求める .

5. $r=\tau / F$ より有効半径 $r$ 及び $d r / d \theta$ を $\theta$ の関数として求める.

6. 式 (7) より $w$ を $\theta$ の関数として求め, 式 (10), 式 (11) を用いて非円形プーリの形状 $r_{p}^{\prime}, \theta_{p}^{\prime}$ を求める.

7. $r_{p}^{\prime}$ か想定より大きく円形プーリと干渉する場合や, 非円形プーリの曲率半径 $r_{c}$ が仕樣を満たさない場合等 , 得 られた非円形プーリ形状に問題がある場合には，3.もしくは1.に戻って初期設定を見直し，再度計算を行う． 上記の手順により，所望のトルクプロファイルを実現する調節機構が設計できるようになる . なお , 非円形プー リの曲率半径 $r_{c}$ の求め方については後述する . また , 出力としてカプロファイル $F(u)$ を実現する調節機構を設計 する場合には, 入力側に渦巻きバネのような角変位と発生トルクの関係が一定な機構を想定して, 手順 1. を,

1 '. 出力側の仕事量と見合う非円形プーリの角変位 $\theta$ の範囲と, 非円形プーリに作用するトルクプロファイル $\tau(\theta)$ を初期設定する .

に置き換えて設計を行えばよい.なお，手順 5., 6.において $r$ 等を全て $\theta$ の関数に揃えているが, 手順 4.より $\theta$ と $u$ は相互変換可能なので, 全てを $u$ の関数に揃えて設計することも可能である .

以下に，本手順による設計例を示す．ただし，可撓性部材の機械的特性による制約は無視できるものとし，設計 は $r_{w}=0$ として行う. 


\section{$2 \cdot 3$ 調節機構の設計例}

\subsection{1 設計例 1 (スプリングバランサ $)$}

最初に , 線形バネによるトルクを一定の力に変換 , 調節するスプリングバランサの設計例について示す . スプリ ングバランサの構成としては, 非円形プーリに巻き付けられたワイヤが円形プーリに逆曲げで掛けられる図 1(a) の構成を想定する . スプリングバランサの非円形プーリには, 入力として線形バネによる反時計回りのトルク $\tau$ が作用し, 出力としてワイヤに対する張力 $F$ が発生する．ワイヤの先端に吊り下げた質量 $m$ の荷物重量 $m g(g$ は 重力加速度) と釣り合う張力 $F$ を，ワイヤの変位 $u$ にかかわらず実現するスプリングバランサを設計する .

まず, 非円形プーリに作用する線形バネによるトルク $\tau$ が， $0 \leqq \theta \leqq \theta_{\max }$ の範囲で以下のように表せるとする．

$$
\tau(\theta)=k \theta+\tau_{0}
$$

$\theta$ は非円形プーリの角変位であり, 非円形プーリが時計回りに回転してワイヤがほどかれていく方向が正となる. また， $k$ はバネ定数， $\tau_{0}$ は $\theta=0$ におけるトルクである .一方，ワイヤに作用する張力 $F$ は, $0 \leqq u \leqq u_{\max }$ のいず れの位置においても，

$$
F=m g
$$

となる.$u$ はワイヤが下方に変位する方向が正となる.$u$ と $\theta$ の関係は, 位置エネルギーの減少分と弾性エネル ギーの増加分が等しくなることから，

$$
u=\frac{1}{m g}\left(\frac{k}{2} \theta^{2}+\tau_{0} \theta\right)
$$

と求められる．フルストローク時の仕事量が等しいので，

$$
u_{\max }=\frac{1}{m g}\left(\frac{k}{2} \theta_{\max }^{2}+\tau_{0} \theta_{\max }\right)
$$

となり，これを $\theta_{\max }$ について解くと，

$$
\theta_{\max }=\frac{-\tau_{0}+\sqrt{\tau_{0}^{2}+2 k m g u_{\max }}}{k}
$$

となる. $\theta$ の関数として非円形プーリの有効半径 $r$ を表すと,

$$
r(\theta)=\frac{\tau(\theta)}{F}=\frac{k \theta+\tau_{0}}{m g}
$$

となるので, 式(7)より，

$$
w(\theta)=\frac{\sqrt{m^{2} g^{2} b^{2}-\left(k \theta+\tau_{0}+m g r_{r}\right)^{2}}}{\sqrt{m^{2} g^{2} b^{2}-\left(k \theta+\tau_{0}+m g r_{r}\right)^{2}}-k} \frac{k}{m g}
$$

と求められる . 目標のカプロファイル $F=m g$ 及び最大変位 $u_{\max }$ が与えられ, 設計パラメータの $k, \tau_{0}, b, r_{r}$ を設定 すると, $r(\theta), w(\theta)$ を用いてスプリングバランサを実現する非円形プーリの形状か容易に求められるようになる .

例として $, m=50 \mathrm{~kg}, u_{\max }=1 \mathrm{~m}, k=1 \mathrm{~N} \cdot \mathrm{m} / \mathrm{rad}, \tau_{0}=15 \mathrm{~N} \cdot \mathrm{m}, b=160 \mathrm{~mm}, r_{r}=30 \mathrm{~mm}$ としてスプリングバラン サを設計した結果を図 3 に示す. 図 3 には, 円形プーリと角変位 $\theta=0$ における非円形プーリを示すと共に, 角 変位 $\theta=0,2 \pi, 4 \pi, 6 \pi$ における可撓性部材の位置を破線で示している . 非円形プーリについては, 点 $\mathrm{P}$ を $\theta$ の動 作範囲全域にわたってプロットした形状のみを示しており，谷の他の部分については省略している.座標軸の設 定は図 1 と同樣である .この非円形プーリは，ワイヤを複数回巻き付ける形状になるため，実際には円錐螺旋状 の形状となり，ワイヤの引き出し位置が紙面垂直方向に変動する構造となる．ただし本設計例においては, 紙面 垂直方向の変位による影響については無視できるものとしている.また, 図 3 に○印で示しているのは式(8), 式

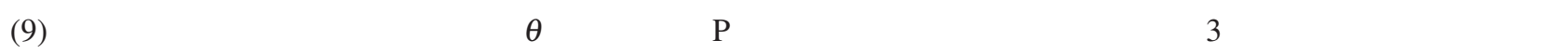
変位 $\theta=0,2 \pi, 4 \pi, 6 \pi$ における点 $\mathrm{P}$ の位置が, いずれも非円形プーリと円形プーリとの共通接線の接点になってい ることが確認できる.さらに，図 4 には図 3 の非円形プーリを角変位 $\theta=\pi$ における状態に置き換えたものを示 している.図 4 における破線は, $\theta=\pi, 3 \pi, 5 \pi$ における可撓性部材の位置を示している. 図 3 と同樣に, 角変位 $\theta=\pi, 3 \pi, 5 \pi$ における点 $\mathrm{P}$ の位置が，いずれも非円形プーリと円形プーリとの共通接線の接点になっていること 


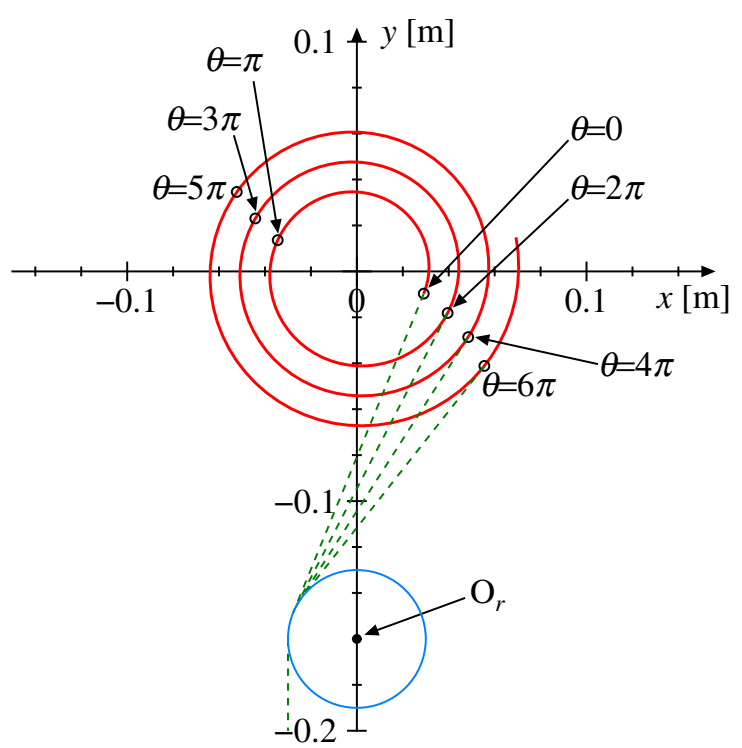

Fig. 3 Configuration of the spring balancer $(\theta=0)$.

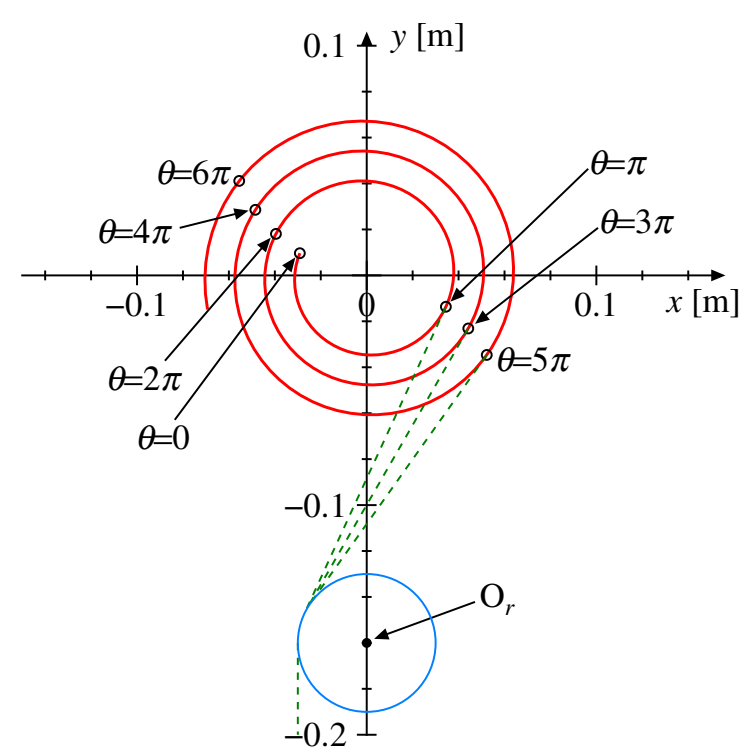

Fig. 4 Configuration of the spring balancer $(\theta=\pi)$.

が確認できる．したがって，提案する解析的設計法を用いることで, 非円形プーリの角変位 $\theta$ に対して有効半径 を $r(\theta)$ とする非円形プーリの形状を得ることができ, カプロファイル $F$ を実現するスプリングバランサの設計が 行えることか確認できた .

\section{2·3·2 設計例 2(アーム自重補償機構)}

次に, アームの自重により発生するトルクを線形バネの力で補償する自重補償機構の設計例について示す.自重 補償機構の概要を図 5 に示す．一端を回転自由に固定した引っ張りバネに連結したワイヤを，アームと連動して 回転する非円形プーリに巻き付けることで, アームリンクの先端に固定された質量 $m$ により発生するトルクを補 償する構成となっている . 自重補償機構の非円形プーリには, 入力として引つ張りバネによるワイヤの張力 $F$ が 作用し, 出力としてアームに対するトルク $\tau$ が発生する.アームリンクおよび非円形プーリの質量は無視できる ものとする . アームが鉛直上方を向いている状態を $\theta=0$ とし，アームの動作範囲を $-\theta_{\max } \leqq \theta \leqq 0$ とする .た だし， $\theta_{\max } \leqq \pi て ゙ あ り ， \theta$ は時計回りを正とする．質量 $m$ により生じるトルクを補償するためには，

$$
\tau(\theta)=-m g l \sin \theta
$$

だけの時計回りのトルクを非円形プーリにより実現させる必要がある .一方, 自然長 $L_{0}$ からの伸びが $-u_{\max } \leqq u \leqq 0$ の範囲で変化する引つ張りバネの発生力が, , バネ定数を $k$ として,

$$
F(u)=-k u
$$

で表されるとする.補償力の必要ない $\theta=0$ において $u=0$ になるとしたとき,$u$ と $\theta$ の関係は位置エネルギーの 減少分と弾性エネルギーの増加分が等しくなることから，

$$
u=-\sqrt{\frac{2 m g l}{k}(1-\cos \theta)}=2 \sqrt{\frac{m g l}{k}} \sin \frac{\theta}{2}
$$

と求められる・よって，

$$
u_{\max }=2 \sqrt{\frac{m g l}{k}} \sin \frac{\theta_{\max }}{2}
$$

となる . 張力 $F$ を $\theta$ の関数として表すと,

$$
F(\theta)=-2 \sqrt{m g l k} \sin \frac{\theta}{2}
$$




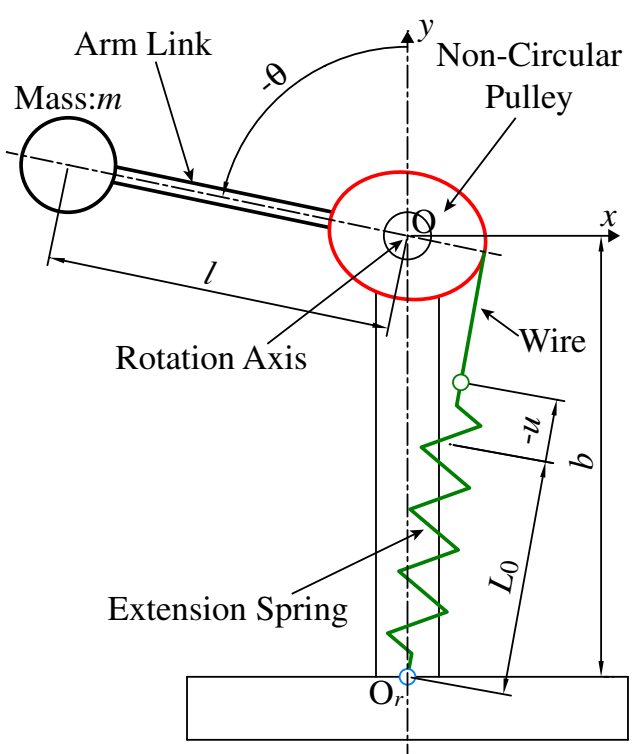

Fig. 5 Schematic drawing of the weight compensation mechanism.

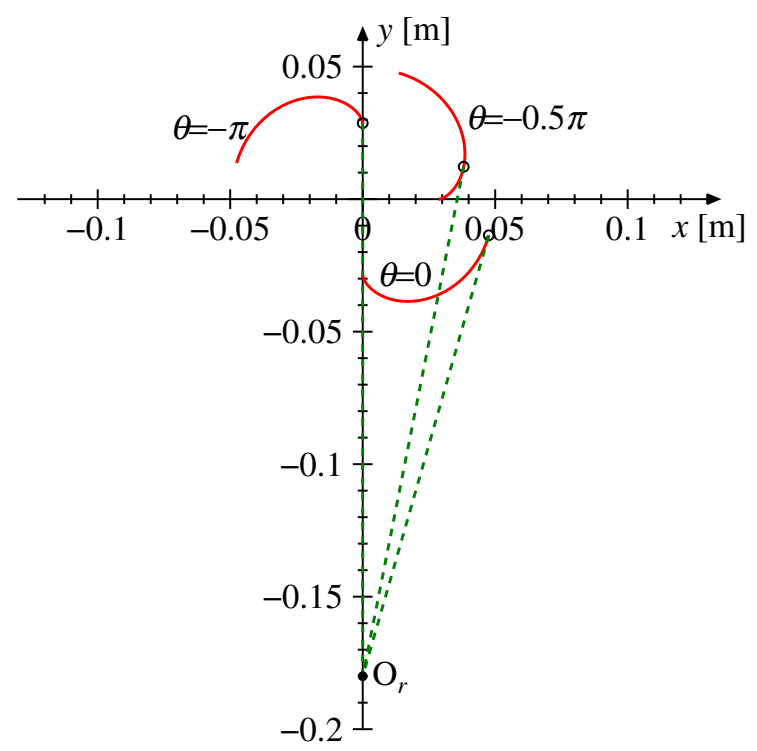

Fig. 6 Configuration of the weight compensation mechanism $(\theta=0,-0.5 \pi,-\pi)$.

となるので, 非円形プーリの有効半径 $r(\theta)$ は ,

$$
r(\theta)=\frac{\tau(\theta)}{F(\theta)}=\sqrt{\frac{m g l}{k}} \cos \frac{\theta}{2}
$$

と求められる．また式(7)より， $r_{r}=0$ として，

$$
w(\theta)=-\frac{\sqrt{b^{2}-\frac{m g l}{k} \cos ^{2} \frac{\theta}{2}}}{2 \sqrt{\frac{k b^{2}}{m g l}-\cos ^{2} \frac{\theta}{2}}+\sin \frac{\theta}{2}} \sin \frac{\theta}{2}
$$

が得られる.目標のトルクプロファイル $\tau(\theta)$ 及び最大角変位 $\theta_{\max }$ が与えられ，設計パラメータの $k, b$ を設定す ると, $r(\theta), w(\theta)$ を用いて自重補償機構を実現する非円形プーリの形状が容易に求められるようになる.

例として, $\theta_{\max }=\pi, m=0.5 \mathrm{~kg}, l=500 \mathrm{~mm}, k=1 \mathrm{~N} / \mathrm{mm}, b=180 \mathrm{~mm}$ として自重補償機構を設計した結果を図 6

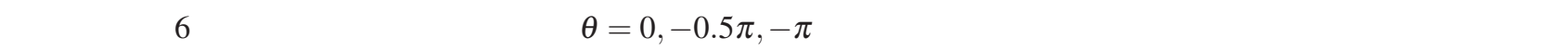
の角変位における可撓性部材の位置を破線で示している.非円形プーリについては, 点 $\mathrm{P}$ を $\theta$ の動作範囲全域に わたってプロットした形状のみを示しており，弚の他の部分については省略している．座標軸の設定は図 1 と同 樣である.また, 図 6 に○印で示しているのは式(8), 式 (9) より求められる光れ光れの角変位 $\theta$ における点 $\mathrm{P} の$ 位置である. 角変位 $\theta=0,-0.5 \pi,-\pi$ の光れ光れにおいて点 $\mathrm{P}$ の位置が可撓性部材と非円形プーリの接点になっ ていることが確認できると共に, $\theta=-\pi$ における点 $\mathrm{P}$ は $y$ 軸上に位置し, 遠藤らの数值的繰り返し計算手法 ${ }^{(8)}$ と 同樣に有効半径 $r$ が 0 になることが確認できる．したがって，提案する解析的設計法を用いることで，トルクプ ロファイル $\tau$ を実現する自重補償機構の設計が行えることが確認できた . 今回の設計例のように， $\theta=0$ からの変 化で可撓性部材が非円形プーリに巻き付けられていく構成の場合には, $\theta$ が負の方向に変化するように考えること で，ほどかれていく場合と同樣に非円形プーリの形状を計算できるようになる．なお，図に示された部分以外の 非円形プーリの形状については, ワイヤの固定が可能かつ, 非円形プーリの回転範囲全域にわたつてワイヤ等の 他の部材に接触しない形状であれば任意に定めることができる .

以上, 提案した設計法により非円形プーリの形状が解析的に求められ, カ/トルクプロファイル調節機構の設 計が行えることを示した . 上記設計例に限らず, 本設計法は樣々な構成に対して適用可能である.変位や角変位に 
伴うエネルギー変化の計算ができればよいので, 弾性要素として線形バネの代わりに非線形バネを用いる場合な どにも対応可能である .

\section{3. 非円形プーリの設計限界}

前節において, $\theta$ で微分可能な有効半径 $r(\theta)$ を定めることで, カ/トルクプロファイル調節機構における非円 形プーリの形状か解析的に求められることを示した．したがって，微分可能であればどのようなプロファイルの $r(\theta)$ に対しても計算結果が得られることになる . ただし , 得られる非円形プーリの形状か現実的な形状になると は限らず, 非円形プーリを用いて任意のカ/トルクプロファイルを得るためには，弚の設計限界を明らかにするこ とが重要になる．しかし，これまでに非円形プーリの設計限界についての報告はなされておらず, 試行錯誤的な 設計パラメータ調節に頼らざるを得なかった . 本節では, 非円形プーリの形状に問題が生じるケースについて示 し，弚の対応策について検討する。

\section{$3 \cdot 1$ 有効半径 $r$ が過大になるケース}

形状に問題が生じる最も単純なケースは，有効半径 $r(\theta)$ が大きくなりすぎる場合である . 式 (1) より，このよ うなケースは $F(\theta)$ が 0 に近づくにもかかわらず $\tau(\theta)$ が 0 とならない場合に発生する.対応策としては， $F(\theta) を$ 円形プーリ等を用いてトルクに変換し, 同樣に $\tau(\theta)$ を円形プーリ等を用いてカに変換することで, 非円形プーリ

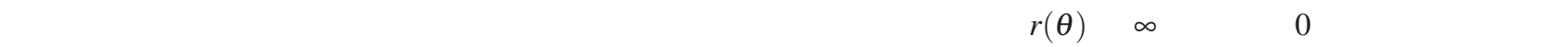
るので, 非円形プーリのサイズが大きくなりすぎることはなくなる.ただし, 元々の構成において $r(\theta)$ が 0 に近 い值をとることがある場合には, トルクとカの関係を反転させるだけでは問題が解決できないので, 調節機構の 構成を変更してカ／トルクプロファイル自体を見直すことが必要になる．

\section{$3 \cdot 2$ オフセット長 $w$ が過大になるケース}

非円形プーリが回転する際に周辺に必要になる空間の大きさは, 動径 $r_{p}$ の最大值に依存する . 動径 $r_{p}$ は, 式 (8) で示される通り $r$ と $w$ により決定されるので, $r_{p}$ の最大值を抑えるには $r$ が過大になるケースだけでなく $w$ が 過大になるケースについても注意する必要がある $w(\theta)$ は式 (7) で表されるので，

$$
\frac{d r}{d \theta}=\sqrt{b^{2}-\left(r \pm r_{r}\right)^{2}}
$$

の状態に近づくにつれて $w(\theta)$ は $\pm \infty に$ に発散することがわかる .この現象を図 2 を用いて説明する . 図 2 において 直線 $\mathrm{Q} \mathrm{P}^{\mathrm{P}}$ が直線 $\mathrm{QP}$ より長い時, 点 $\mathrm{P}$ が接点となるためには, 点 $\mathrm{P}$ 'と直線 $\mathrm{OQ}$ との距離が点 $\mathrm{P}$ と直線 $\mathrm{OQ}$ の距 離を上回らないだけの直線 OQ' の長さが必要になる . 必要となる長さは $\theta_{2}$ が小さいほど大きくなるので, $\theta_{2}=0$ に近づくにつれてゅに発散することになる．したがって，式(6)を0 と置くことでも式 (26) が導かれる.式 (3)よ り, $\theta_{2}$ は角変位 $\theta$ の変化量と $\phi(\theta)$ の変化量の差を表しているので, $\theta_{2}=0$ とは両者が一致する状態にあること を示している.$\phi(\theta)$ の変化量がさらに大きくなると $\theta_{2}$ が負の值になるため,$w(\theta)$ も負の值に変化することにな る.なお, 図 1 のプーリの構成上, 式 (26) の右辺は常に正の值となるので, $w(\theta)$ が $\pm \infty に$ 発散する問題は $d r / d \theta$ が正の值の場合にのみ発生しうる. 問題の発生する例として, $0 \leqq \theta \leqq \pi の$ 範囲で無次元有効半径 $R(\theta)$ が，

$$
R(\theta)=e^{\theta}
$$

となる非円形プーリを考える.$R(\theta)$ は $r(\theta)$ を $r(0)$ で無次元化したものであり，以下 $r(0)$ で無次元化した寸法を 大文字で表す. 調節機構を $R_{r}=5$ の逆曲げ構成として設計した結果を図 7 , 図 8 に無次元寸法で示す. 図中の○印 は, 該当する角変位 $\theta$ における点 $\mathrm{P}$ の位置を示している. 図 7 が $B=50$ における結果であり, 図 8 が $B=30$ に おける結果である . 図 7 の結果では，無次元動径 $R_{p}$ の最大值が 57.4 となり $B$ よりも大きい形状になっているが， 角変位が $0 \leqq \theta \leqq \pi$ の範囲では円形プーリと干渉せず, 動作可能な構造であることがわかる.しかし，より構成 をコンパクトにするために $B=30$ に縮めると，図 8 に示されるように $\theta \doteqdot 0.93 \pi$ において式 (26) が成立し， $w(\theta)$ が士心に発散する現象が発生してしまう．この場合，非円形プーリのサイズは無限に大きくなるとともに，計算 された外形は二つの部分に分断されてしまい，実現不可能な形状になることがわかる. 


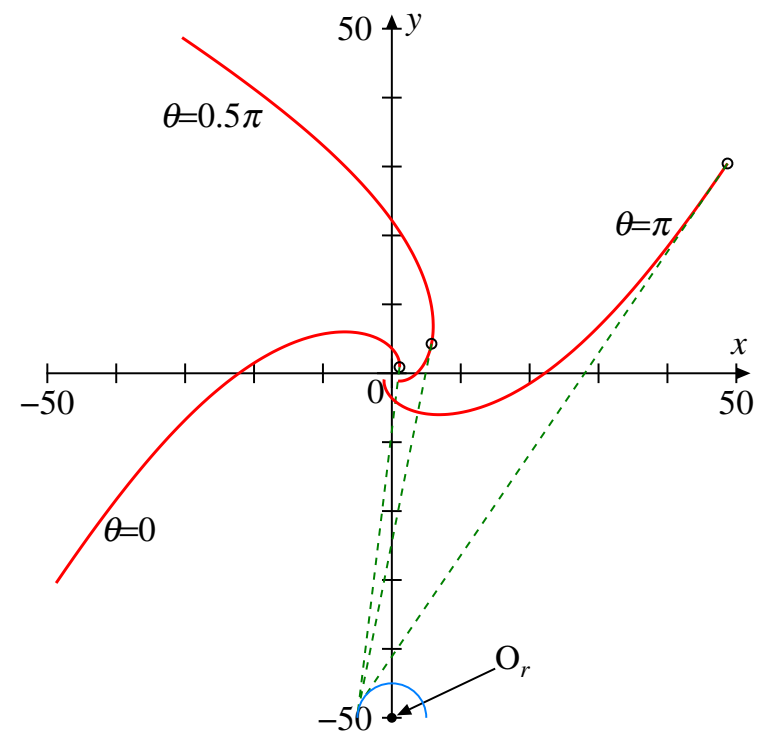

Fig. 7 Example of adjustment mechanism avoiding excessive offset $w(\theta=0,0.5 \pi, \pi)$.

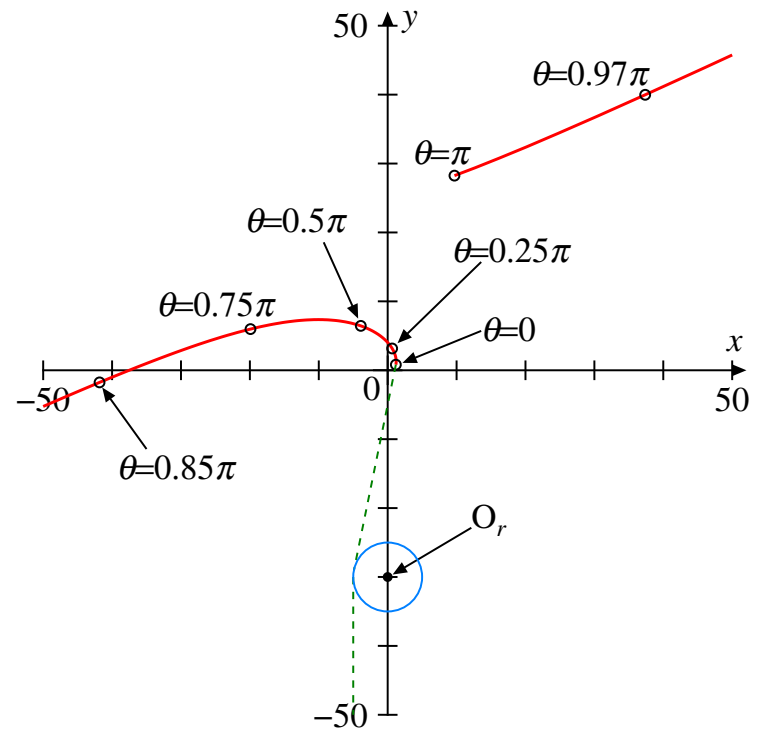

Fig. 8 Example of adjustment mechanism including excessive offset $w(\theta=0)$.

このようなケースにおける対応策としては，

$$
\frac{d r}{d \theta}<\sqrt{b^{2}-\left(r \pm r_{r}\right)^{2}}
$$

が余裕を持って満たされるように, 非円形プーリと円形プーリの中心間距離 $b$ を十分に確保しておくことが挙げ られる.$b$ が増加するほど式 $(26)$ は成立しにくくなる .これは,$\phi(\theta)$ の変化量を抑制するのと同じことになる $b=\infty$ となり可撓性部材の引き出し方向が一定になった場合には $w(\theta)=d r / d \theta$ となるので, 問題が発生すること は無くなる.この場合， $\phi(\theta)$ は 0 のまま変化しなくなる.また,$b$ を大きくしたない場合には, 調節機構の構 成を変更してカ/トルクプロファイルの見直しを行い, $d r / d \theta$ を抑制する方法も挙げられる . また , 図 1(a) の逆 曲げ構成よりも図 1(b) の順曲げ構成とした方が式 (28)の右辺が大きくなるので, $w(\theta)$ は発散しにくくなる.さら に,$r=\infty$ となるケースでの対策と同樣にトルクと力の関係を反転させると,$d r / d \theta$ の符号が反転するので, $r(\theta)$ が単純増加している場合には有効な対策となりうる．

$3 \cdot 3$ 曲率半径 $r_{c}$ が過小になるケース

最後のケースは, 非円形プーリ外形の曲率半径が小さくなりすぎる場合である. 非円形プーリ外形の曲率半径 は，光こに巻き付けられる可撓性部材の耐久性や永久ひずみの発生に影響するため，使用する可撓性部材によって 許容できる最小值が決まる. 光のため, 曲率半径を把握することは設計上重要となる. 非円形プーリ外形の曲率 半径 $r_{c}$ は, $r_{p}\left(\theta_{p}\right)$ を用いて,

$$
r_{c}=\frac{\left[r_{p}^{2}+\left(\frac{d r_{p}}{d \theta_{p}}\right)^{2}\right]^{1.5}}{r_{p}^{2}+2\left(\frac{d r_{p}}{d \theta_{p}}\right)^{2}-r_{p} \frac{d^{2} r_{p}}{d \theta_{p}^{2}}}
$$

と表される．しかし， $r_{p}\left(\theta_{p}\right)$ による表現では設計上の制約の理解が困難になるので, 有効半径 $r(\theta)$ を用いた表現 に変換する .ここで, 以下のように定義する .

$$
\dot{r} \equiv \frac{d r}{d \theta}, \quad \ddot{r} \equiv \frac{d^{2} r}{d \theta^{2}}
$$




$$
\dot{w} \equiv \frac{d w}{d \theta}=\frac{\left[b^{2}-\left(r \pm r_{r}\right)^{2}\right] \ddot{r}+\frac{r \pm r_{r}}{\sqrt{b^{2}-\left(r \pm r_{r}\right)^{2}}} \dot{r}^{3}}{\left[\sqrt{b^{2}-\left(r \pm r_{r}\right)^{2}}-\dot{r}\right]^{2}}=\frac{\ddot{r} w^{3}+\left(r \pm r_{r}\right)(w-\dot{r})^{3}}{\dot{r}^{2} w}
$$

$\theta_{p}$ を $\theta$ で微分すると，

$$
\frac{d \theta_{p}}{d \theta}=1-\frac{\dot{r}}{\sqrt{b^{2}-\left(r \pm r_{r}\right)^{2}}}+\frac{r \dot{w}-\dot{r} w}{r^{2}+w^{2}}=\frac{r(r \dot{r}+w \dot{w})}{w\left(r^{2}+w^{2}\right)}
$$

となる $. r_{p}=\sqrt{r^{2}+w^{2}}$ より，

$$
\begin{gathered}
\frac{d r_{p}}{d \theta_{p}}=\frac{\frac{d r_{p}}{d \theta}}{\frac{d \theta_{p}}{d \theta}}=\frac{w}{r} \sqrt{r^{2}+w^{2}} \\
\frac{d^{2} r_{p}}{d \theta_{p}^{2}}=\frac{\frac{d}{d \theta}\left(\frac{d r_{p}}{d \theta_{p}}\right)}{\frac{d \theta_{p}}{d \theta}}=\frac{w(r \dot{w}-\dot{r} w)}{r^{3}(r \dot{r}+w \dot{w})}\left(r^{2}+w^{2}\right)^{1.5}+\frac{w^{2}}{r^{2}} \sqrt{r^{2}+w^{2}}
\end{gathered}
$$

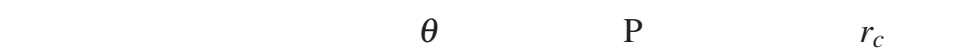

$$
r_{c}=\frac{\left[r^{2}+w^{2}+\frac{w^{2}}{r^{2}}\left(r^{2}+w^{2}\right)\right]^{1.5}}{r^{2}+w^{2}+\frac{w^{2}}{r^{2}}\left(r^{2}+w^{2}\right)-\frac{w(r \dot{w}-\dot{r} w)}{r^{3}(r \dot{r}+w \dot{w})}\left(r^{2}+w^{2}\right)^{2}}=r+\frac{\dot{w}}{\dot{r}} w=r+\frac{\left[b^{2}-\left(r \pm r_{r}\right)^{2}\right]^{1.5} \ddot{r}+\left(r \pm r_{r}\right) \dot{r}^{3}}{\left[\sqrt{b^{2}-\left(r \pm r_{r}\right)^{2}}-\dot{r}\right]^{3}}
$$

で表される . 式 (35) より, 有効半径 $r$ やオフセット長 $w$ がゅになる状態では曲率半径 $r_{c}$ も同樣にめになることが わかる. また曲率半径 $r_{c}$ は, $r=-\dot{w} w / \dot{r}$ となるときに 0 となるが，これは図 2 における点 $\mathrm{P}$ ' と直線 $\mathrm{QP}$ の距離，

$$
\delta^{\prime}\left(\theta_{1}\right) \equiv\left(r+\frac{d r}{d \theta} \theta_{1}\right) \sin \theta_{2}+\left(w+\frac{d w}{d \theta} \theta_{1}\right) \cos \theta_{2}-w
$$

が ,

$$
\left(\frac{\partial \delta^{\prime}}{\partial \theta_{1}}\right)_{\theta_{1}=0}=0
$$

となる条件である．すなわち $r_{c}=0$ とは, $\theta$ を増加させながら非円形プーリの形状を極座標上にプロットしてい く際に，点 $\mathrm{P}$ の進行方向が反転する頂点の位置にあることを示している．実用的な非円形プーリ形状であるため には, $r_{c}$ が可撓性部材の許容できる最小曲率半径を常に上回る必要がある.

さらに, 曲率半径 $r_{c}$ が過小になるケースとしては, $r_{c}$ の值が負になるケースもありうる . 曲率半径が負になる 場合に生じる現象について示すために, $0 \leqq \theta \leqq \pi の$ 範囲で無次元有効半径 $R(\theta)$ が，

$$
R(\theta)=1-0.4 \sin (2 \theta)
$$

となる非円形プーリを考える $R(\theta)$ は $r(\theta)$ を $r(0)$ で無次元化したものであり，以下 $r(0)$ で無次元化した寸法を 大文字で表す. $B=3.5, R_{r}=0.5$ の順曲げ構成として設計した結果を図 9 に無次元寸法で示す . このときの $\theta$ と無 次元曲率半径 $R_{c}$, 無次元有効半径 $R$, 無次元動径 $R_{p}$ との関係を図 10 に示す. 図 9 では, 非円形プーリの外形は 二度折れ曲がる形状となっているが, 折れ曲がりは図 10 において $R_{c}=0$ となる際に発生している.正の值であ るべき無次元曲率半径 $R_{c}$ は $\theta \doteqdot 0.56 \pi$ および $\theta \doteqdot 0.78 \pi$ において 0 となり，乥の間において負の值となっている. このように最小の曲率半径が負になるような条件では, 計算される非円形プーリの形状は図 9 のような折れ曲がっ た形状を示すことになり，実現不可能な形状となる．

ここで, 曲率半径に影響を与える要因について分析し, 最小值を向上させるための対策について検討する .まず，

$$
\alpha \equiv \sqrt{b^{2}-\left(r \pm r_{r}\right)^{2}}, \quad \beta \equiv \dot{r}
$$

とすると, 曲率半径 $r_{c}$ は,

$$
r_{c}=r+\left(\frac{\alpha}{\alpha-\beta}\right)^{3} \ddot{r}-\left(\frac{\beta}{\beta-\alpha}\right)^{3}\left(r \pm r_{r}\right)
$$




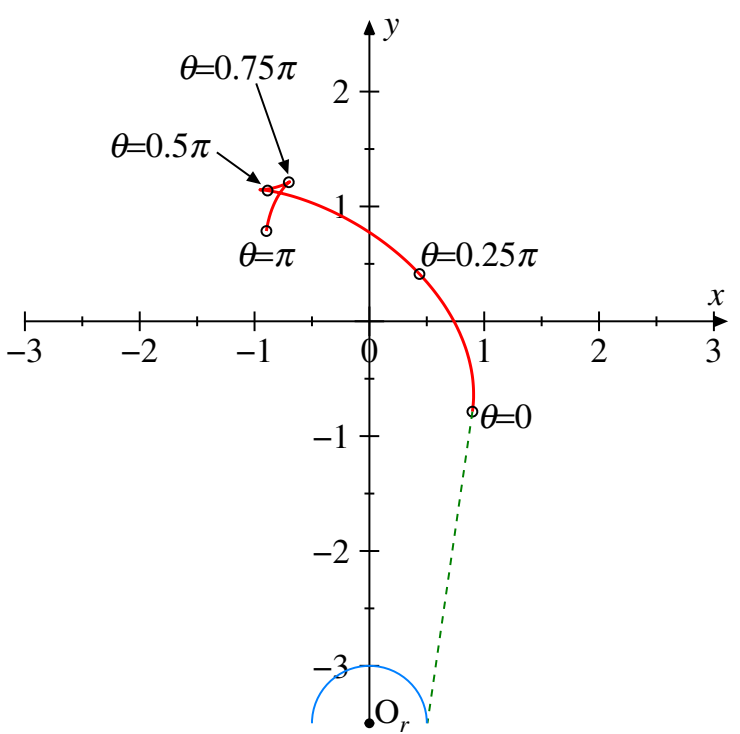

Fig. 9 Example of adjustment mechanism including negative $R_{c}(\theta=0)$.

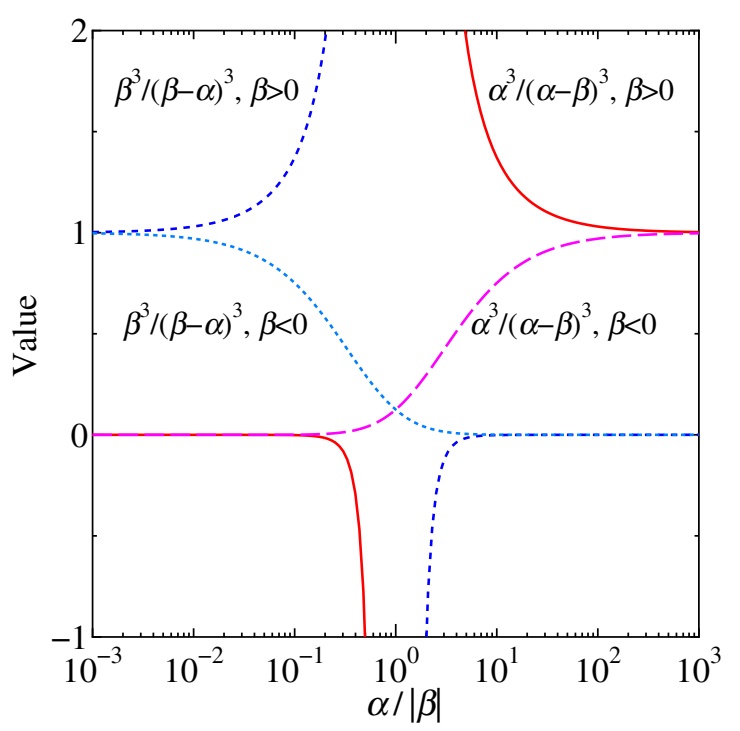

Fig. 11 Values concerning the radius of curvature, $r_{c}$ against $\alpha / \beta$.

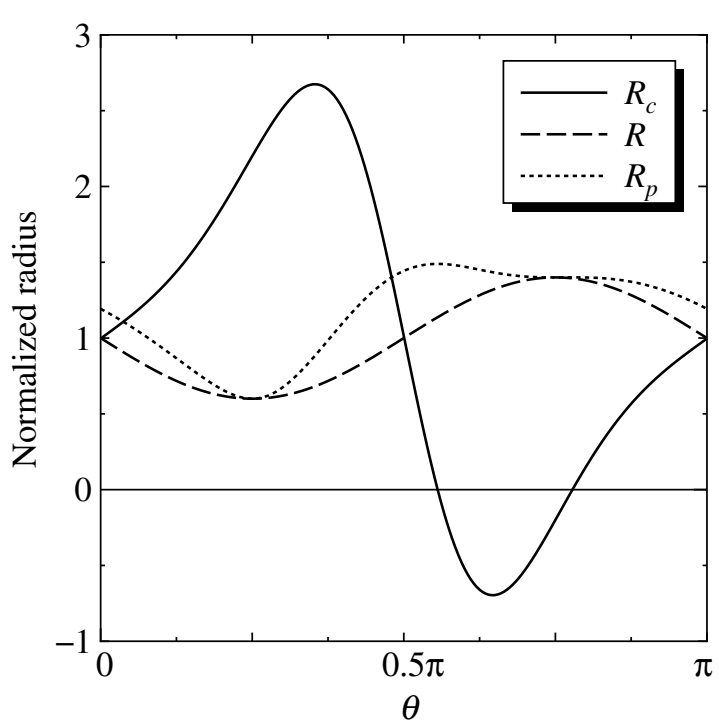

Fig. 10 Various normalized radii against the rotation angle $\theta$.

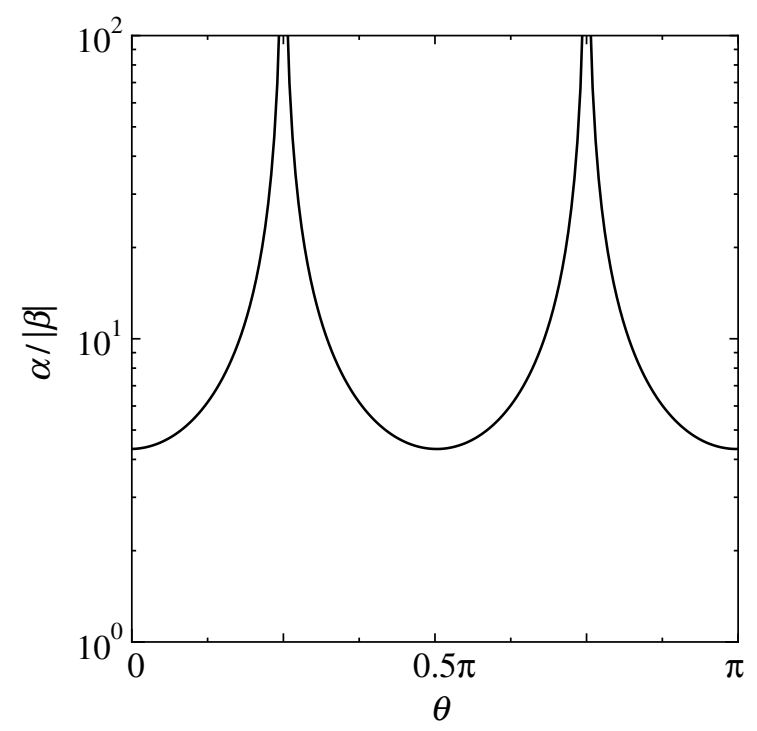

Fig. 12 Relation between the rotation angle $\theta$ and $\alpha /|\beta|$.

と書き換えられる． $\alpha$ は非円形プーリと円形プーリの共通接線の長さを表し，常に正の值である一方で, $\beta$ は正 負いずれの值でも取り得る. $\alpha^{3} /(\alpha-\beta)^{3}$ と $\beta^{3} /(\beta-\alpha)^{3}$ に対する $\alpha / \beta$ の影響を图 11 に示す . $\alpha / \beta$ が 1 に近い 場合，いずれの值も \pm にに発散していくが，これは 3.2 で示したケースが発生するためである. 弚れ以外の部分 における結果からは， $\alpha>|\beta|$ の場合は $\ddot{r} に$ 掛かる值が支配的になり， $\alpha \gg|\beta|$ において $r_{c}=r+\ddot{r}$ となることがわ かる．また， $|\beta|>\alpha$ の場合は $r \pm r_{r}$ に掛かる值が支配的になり， $|\beta| \gg \alpha$ において $r_{c}=\mp r_{r}$ となることがわかる . 以上から , 曲率半径 $r_{c}$ の最小值を向上させるための対策について次のような知見が得られる .

1. 力/トルクプロファイルを見直して,$\alpha>|\beta|$ となる範囲や $\beta<0$ となる範囲において $r$ の増加を図る .

2. カ/トルクプロファイルを見直して,$\alpha>|\beta|$ となる範囲において $\boldsymbol{r}$ の最小值の増加を図る . これは $\beta>0$ の 
場合の方が効果的である .

3. 逆曲げの構成の場合, 順曲げの構成に変更する.これは $\alpha<|\beta|$ となる範囲で特に $\beta>0$ の場合に効果的で ある

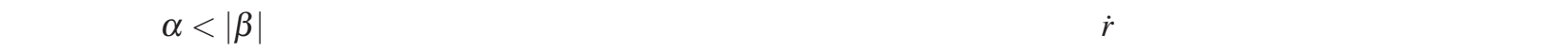
えば， $\alpha$ は $b$ を極端に増加させなくても $r$ 以上の值になるのに対して， $|\beta|$ を $r$ 以上の值にするには $r$ か指数関数 のような急激な変化をする必要がある.$r$ の急激な変化は, 非円形プーリと円形プーリの干渉を防ぐために必要と される $b$ の増加，すなわち $\alpha$ の向上につながりやすいことから， $\alpha<|\beta|$ となるのは特殊なケースといえる．よっ て実際の設計時には， $\alpha /|\beta|$ がおおよ光 3 以上となるように $b$ を設定し， $\ddot{r}$ に掛かる值が支配的になる状態にし て,$r$ と $\ddot{r} に$ 着目したカ/トルクプロファイルの見直しを行うのか効率的だと考えられる .ただし $\beta>0$ の場合に は，図 11 から明らかなように $\ddot{r}$ の影響を大きめに見積もる必要がある . 図 9 のケースについて考えると， $\alpha /|\beta|$ は図 12 に示すようになっている. $\theta=0.25 \pi, 0.75 \pi$ において值が発散しているが，これは $\dot{R}=0$ となるためであ る. 乥れ以外の部分でも $\alpha /|\beta|>4$ になっているので, 図 11 からは $R_{c}$ の決定において $\ddot{R}$ に掛かる值が支配的で あると判断できる．したがって， $R$ を増加もしくは苂の最小値を増加させることでプーリ形状の折れ曲がりが解 消できると考えられる．

ここで, 一定力 $F$ を入力して時計回りのトルク $\tau(\theta)=F r(0) R(\theta)$ を出力する調節機構について考える. 弚のま ま設計すると, 非円形プーリの形状が図 9 のようになり実現不可能になるが，ここでは例として $R$ を増加させる ことでプーリ形状の折れ曲がりを解消させる対応策について述べる . 図 9 で示される調節機構の非円形プーリに 対して, 新たに反時計回りの一定トルク $F r(0)$ が作用するように構成を追加する . 例えば, 非円形プーリと連動し て同軸に回転する半径 $r(0)$ の円形プーリと，兴れに巻き付けられる可撓性部材とを追加し，可撓性部材を一定力 $F$ で引つ張るようにする .このようにすると, 調節機構から出力されるトルクは非円形プーリの無次元有効半径 を $R^{\prime}$ として ,

$$
\tau(\theta)=\operatorname{Fr}(0)\left[R^{\prime}(\theta)-1\right]
$$

と表される．したがって，

$$
R^{\prime}(\theta)=R(\theta)+1=2-0.4 \sin (2 \theta)
$$

となる非円形プーリが実現できれば，目的とする出力 $\tau(\theta)$ が実現できることになる $. B, R_{r}$ を変更せずに設計した 結果を図 13 に示す.また, 弚のときの角变位 $\theta$ と無次元曲率半径 $R_{c}^{\prime}$, 無次元有効半径 $R^{\prime}$, 無次元動径 $R_{p}^{\prime}$ との関 係を図 14 に示す.図 13 , 図 14 より，調節機構の構成を見直して $R$ を 1 増加させることで非円形プーリの折れ曲 がりが解消され，目的とする出力 $\tau(\theta)$ を実現できる非円形プーリの形状が得られていることが確認できる.なお この調節機構の構成では, 非円形プーリの形状が図 9 より大きくなっていることからもわかるように, 非円形プー リに巻き付けられた可撓性部材の変位が本来より増加することになる .これは, 追加した構成との仕事のやりとり が発生するためである．ただし，非円形プーリに巻き付けられた可撓性部材の端と追加した円形プーリに巻き付 けられた可撓性部材の端とを連結し，乥れを動滑車で引つ張るようにすれば，本来の出力トルク分以外の仕事を 行わずにすむようになる . この場合, 動滑車を引つ張る力は $2 F$ となるが, 変位は本来の半分ですむようになる .

次に, 反時計回りの一定トルク $\tau$ を入力して力 $F(\theta)=\tau /[r(0) R(\theta)]$ を出力する調節機構について考える .ここ では例として, 角変位 $\theta$ の範囲を拡大することでR゙の最小值の増加を図り, プーリ形状の折れ曲がりを解消する 対応策について述べる . 角変位 $\theta$ の範囲を $0 \leqq \theta \leqq 1.5 \pi$ に拡大するとともに, 入力するトルクを $2 \tau / 3$ に減少さ せると , 出力される力は非円形プーリの無次元有効半径を $R^{\prime \prime}$ として ,

$$
F(\theta)=\frac{2 \tau}{3 r(0) R^{\prime \prime}(\theta)}
$$

と表される．したがって，

$$
R^{\prime \prime}(\theta)=\frac{2}{3} R\left(\frac{2}{3} \theta\right)=\frac{2}{3}-\frac{0.8}{3} \sin \left(\frac{4}{3} \theta\right)
$$

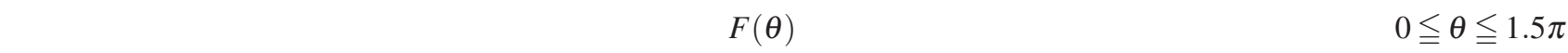
の範囲に対応した $F(\theta)$ と, 本来の $0 \leqq \theta \leqq \pi$ の範囲に対応した $F(\theta)$ とは, 可撓性部材の变位 $u$ を用いて $F(u)$ の 形式で表したときには同一になる. $B, R_{r}$ を変更せずに設計した結果を図 15 に示す . また, 光のときの角変位 $\theta$ と 


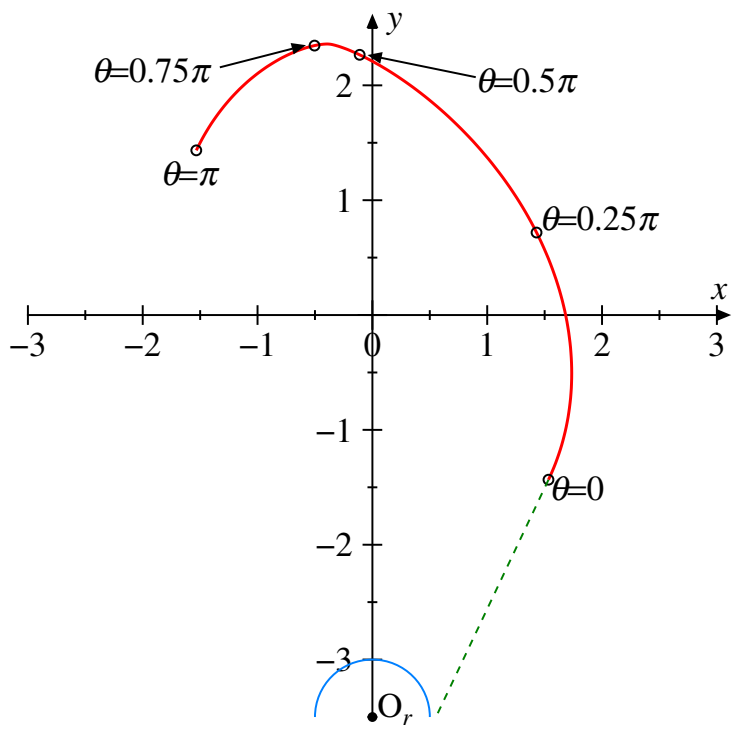

Fig. 13 Example of adjustment mechanism avoiding negative $R_{c}$ by increasing $R(\theta=0)$.

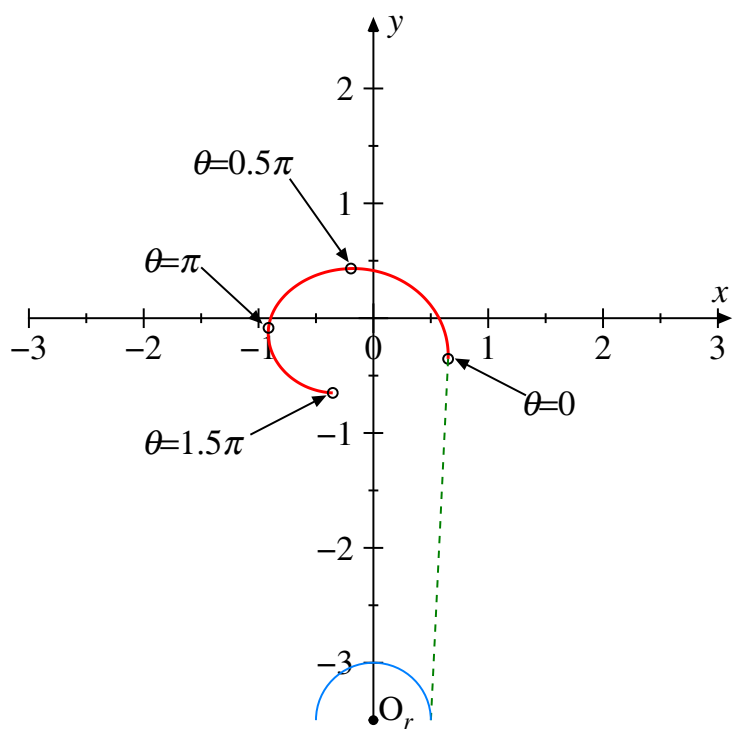

Fig. 15 Example of adjustment mechanism avoiding negative $R_{c}$ by enlarging the range of $\theta(\theta=0)$.

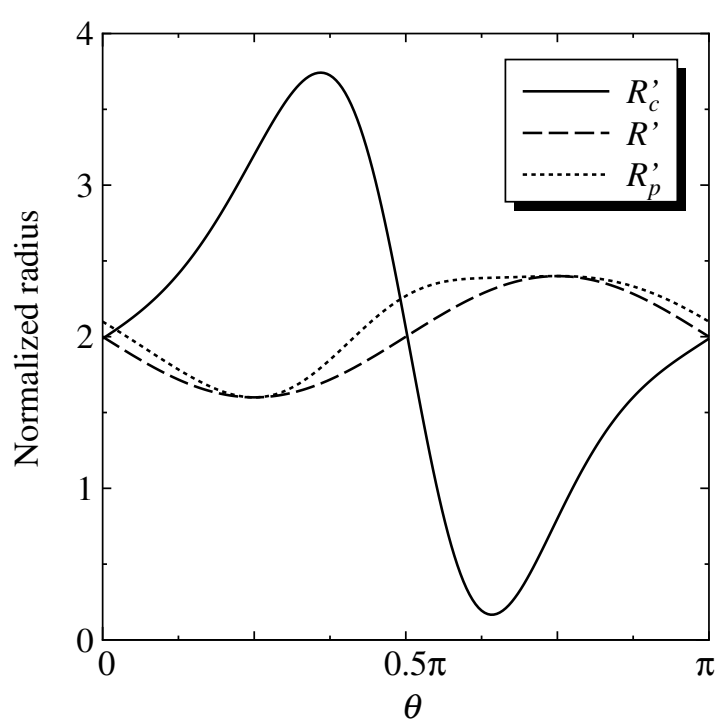

Fig. 14 Various normalized radii avoiding negative $R_{c}$ by increasing $R$.

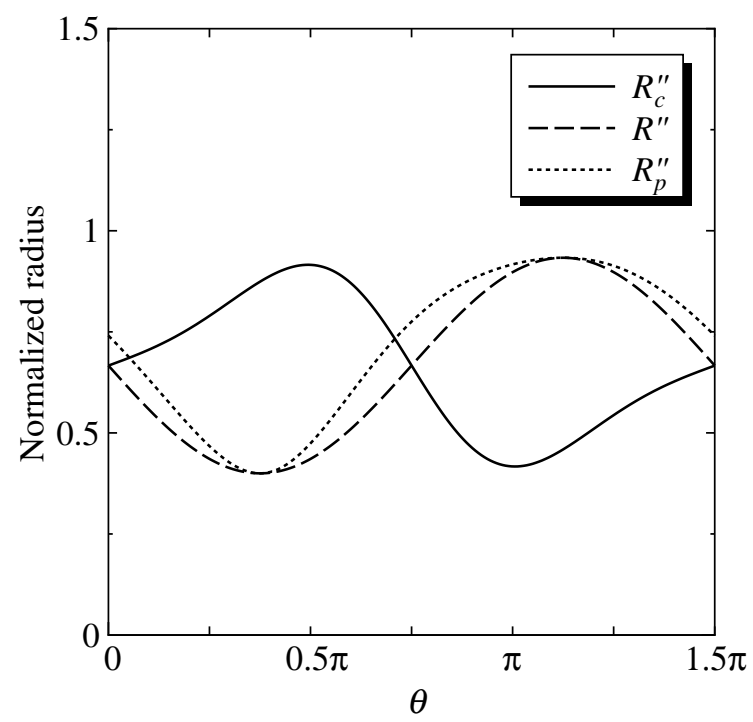

Fig. 16 Various normalized radii avoiding negative $R_{C}$ by enlarging the range of $\theta$.

無次元曲率半径 $R_{c}^{\prime \prime}$, 無次元有効半径 $R^{\prime \prime}$, 無次元動径 $R_{p}^{\prime \prime}$ との関係を図 16 に示す. 図 13 ，図 14 より，調節機構へ の入カトルクの減少と $\theta$ の範囲拡大を行い, 負の值になる $\ddot{R}$ の最小值を $8 / 27$ にすることで非円形プーリの折れ曲 がりが解消され，目的とする出力 $F(\theta)$ を実現できる非円形プーリの形状が得られていることが確認できる .

以上, 曲率半径 $r_{c}$ が過小になるケースについての対応例を示し, 入力側の構成の変更により目的となる出力が 得られる調節機構の設計が行えることを示した．しかし実際の設計では，折れ曲がりのない形状であるだけでな く最小曲率半径や設置空間のサイズ等の樣々な制約条件が追加されることになるので, 今回の対応策を基本に各 種機械要素と組み合わせたり複数の調節機構を用いるなどして, 仕樣を満足する構成を設計していく必要がある. 


\section{4. 結言}

本研究では, カ/トルクプロファイルの調節を可能にする非円形プーリの形状について, 想定される全ての構成 に適用可能な解析方法を明らかにした . 得られた解析手法を用いて, プーリに作用するトルクとプーリに巻き付け られた可撓性部材に作用する張力とを所望のプロファイルになるように変換する機構の設計手順についても示し た .さらに，この設計手順に従ってスプリングバランサとアーム自重補償機構を対象に非円形プーリの設計を行 い, 所望の特性を実現する形状が解析的に求められることを示した . また，計算された非円形プーリが実現可能な 形状になるための設計限界について検討し，形状に問題が生じるケースとして，有効半径 $r$ が過大になる場合，才

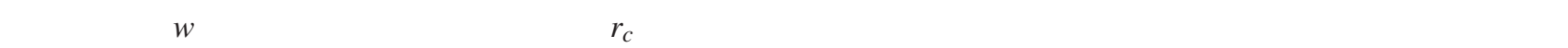

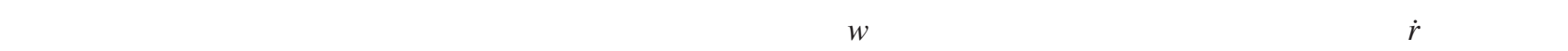
曲率半径 $r_{c}$ が過小になる場合には有効半径 $r$ と有効半径の二階微分 $\ddot{r}$ が大きく影響することが明らかになった .

本研究で得られた結果により，樣々な構成において複雑なプロファイル調節を行う非円形プーリの設計が可能に なったと考えられる．実機への適用については，可撓性部材の強度，伸び，寿命，損失や非円形プーリの製作精 度, 組み立て精度等, 考慮すべき点はあるものの, 非円形プーリを用いたカ/トルクプロファイル調節機構の適 用が本研究により容易になったことで, 今後樣々な機器に対して活用されていくことが期待される .

\section{文献}

(1) 小林一男“" スプリングバランサの設計における基本問題 (スプリングバランサの設計方法および重力バランサとの比較)”, 日本機械学会論文集 C 編，Vol. 64 , No. 622 (1998), pp. 2005-2012.

(2) Kobayashi, K., "New Design Method for Spring Balancers", Transactions of the ASME, Journal of Mechanical Design, Vol. 123, No. 4 (2001), pp. 494-500.

(3) 岡田德次 “ 力発生用パンタグラフ機構の設計” , 日本ロボット学会誌, Vol. 4 , No. 2 (1986), pp. 109-118.

(4) Ulrich, N. and Kumar, V., "Passive Mechanical Gravity Compensation for Robot Manipulators", Proceedings of the 1999 IEEE International Conference on Robotics and Automation, (1991), pp. 1536-1541.

(5) Ulrich, N. and Kumar, V., "Mechanical Design Methods of Improving Manipulator Performance", Proceedings of Fifth International Conference on Advanced Robotics, (1991), pp. 515-520.

（6）広瀬茂男，生田幸士，佐藤光一“形状記憶合金アクチュエータの開発”，日本ロボット学会誌，Vol. 4 , No. 6 (1986), pp. 618-628.

(7) 遠藤玄, 広瀬茂男“; 非円形プーリーバネ系による自重補償機構 パラレルリンクマニピュレータへの適用”, 日本機械学会 ロボティクス・メカトロニクス講演会 2008 講演論文集 , (2008), 1A1-G20.

（8）遠藤玄, 山田浩也 , 矢島明, 尾形勝, 広瀬茂男 "; 非円形プーリーバネ系による自重補償機構と 4 節平行リンク型アームへ の適用”，日本ロボット学会誌，Vol. $28 ，$ No. 1 (2010), pp. 77-84.

(9) Shin, D., Yeh, X., and Khatib, O., "Variable Radius Pulley Design Methodology for Pneumatic Artificial Muscle-based Antagonistic Actuation Systems", Proceedings of 2011 IEEE/RSJ International Conference on Intelligent Robots and Systems, (2011), pp. 1830-1835.

(10) 西岡雅夫, 内野光雄 “ カム式位置決め装置の入力軸トルク補償機構の研究”, 日本機械学会論文集 C 編, Vol. 59 , No. 562 (1993), pp. 1913-1919. 